\title{
In vitro Assessment of Total Bioactive Contents, Antioxidant, Anti-Alzheimer and Antidiabetic Activities of Leaves Extracts and Fractions of Aloe vera
}

\author{
Samira Bendjedid ${ }^{1 *}$, Radia Djelloul ${ }^{1}$, Aicha Tadjine ${ }^{1}$, \\ Chawki Bensouici ${ }^{2}$, and Abbas Boukhari ${ }^{3}$
}

${ }^{1}$ Department of Biology, Faculty of Natural Sciences and Life, Research Laboratory of Functional and Evolutionary Ecology, Chadli Bendjedid University, El Tarf 36000, Algeria

${ }^{2}$ Biotechnology Research Center, Constantine 25000, Algeria

${ }^{3}$ Department of Chemical Sciences, Research Laboratory of Organic Synthesis Modelling and Optimization of the Chemical Processes, Badji Mokhtar University, Annaba 23000, Algeria

*Corresponding author. E-mail: samiraphyto@gmail.com https://doi.org/10.12982/CMUJNS.2020.0031

Received: August 14, 2019

Revised: September 21, 2019

Accepted: September 24, 2019

\begin{abstract}
The present work was conducted to evaluate the quantitative analysis of the leaves of Aloe vera and to evaluate their potential antioxidant, antiAlzheimer and antidiabetic properties in vitro. The acetone extract, methanolic extract and its four fractions were subjected to quantitative determination of polyphenol, flavonoid, flavonol, condensed tannin and hydrolysable tannin contents. Then, the antioxidant properties of all extracts and fractions were evaluated by using DPPH free radical scavenging, ABTS cation radical decolorization, Cupric Reducing Antioxidant Capacity and Metal Chelating Activity assays. Anti-Alzheimer activity was tested against acetylcholinesterase and butyrylcholinesterase enzymes using the Ellman method. The antidiabetic activity was evaluated by using Alpha-Glucosidase Inhibition Assay. The acetone extract showed the highest amount of total phenolic content (TPC), total flavonoid content (TFC), flavonol content (FLC) and total condensed tannins content (TCTC) compared to others extracts and fractions. The water fraction exhibited the low content of TFC, TPC and FLC. The content of total hydrolysable tannins (THTC) varied from $0.94 \pm 0.01$ to $1.22 \pm 0.02 \mu \mathrm{g} \mathrm{TAE} / \mathrm{mg}$ extract. The methanolic extract exhibited highest antioxidant activity in all tests

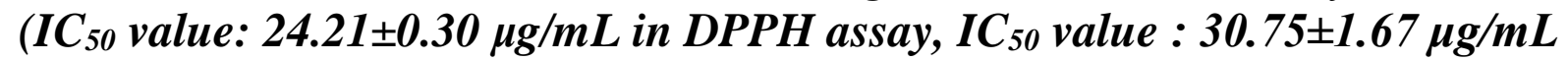
in ABTS assay, IC $C_{50}$ value: $140.99 \pm 2.95 \mu \mathrm{g} / \mathrm{mL}$ in metal chelating activity, and
\end{abstract}


IC 50 value: $17.50 \pm 0.47 \mu \mathrm{g} / \mathrm{mL}$ in CUPRAC assay). Furthermore, the n-butanol fraction indicated the highest $B C h E$ inhibitory activity (IC $C_{50}$ value: $79.61 \pm 2.41$ $\mu \mathrm{g} / \mathrm{ml}$ ) and the good $\alpha$-glucosidase inhibitory activity (IC 50 value: $40.75 \pm 0.06$ $\mu \mathrm{g} / \mathrm{ml}$ ). These results showed that Aloe vera leaves, can be used in food and pharmaceutical industries as natural antioxidants, as well as moderate antiAlzheimer and antidiabetic agents.

Keywords: Aloe vera, Antidiabetic, Anti-Alzheimer, Antioxidant, Extract, Phenolic

\section{INTRODUCTION}

The use of traditional medicine is as old as human, civilization and in many regions of the world is still the primary source of health care. Ayurvedic medicine in India, for example, is still commonly practiced, with approximately $85 \%$ of Indians using crude plant preparations for the treatment of various ailments and diseases (Kamboj, 2000). Even in Western civilizations, plants play an important role in medicine. At least $25 \%$ of pharmaceuticals prescribed worldwide are directly obtained from plants with many more drugs being semi-synthetic derivatives of natural plant precursors (Hostettmann and Hamburger, 1993; Walsh, 2003). Approximately 119 pure chemical substances extracted from higher plants are used in medicine throughout the world (Hoareau and Dasilva, 1999). Examples of medicinally important plant-derived compounds include the anticholinergic drug atropine derived from plants of the family Solanaceae (Atropa belladonna, Datura stramonium and Mandragora officinarum), the analgesics morphine and codeine (from Papaver somniferum), the anti-malarial drug quinine and its derivatives (from Cinchona spp.), the anticancer drug taxol (derived from Taxus brevifolia) (Gilani and Rahman, 2005).

Plants have the capacity to synthesize a large variety of secondary metabolites that are used to perform important biological functions. Since ancient times, many plants have been used for the treatment of many diseases related to the toxic effects of oxidants. Oxidative stress is responsible for several diseases, such as atherosclerosis, arthritis, cardiovascular disorders, Alzheimer's disease and canser (Halliwell, 1999). Alzheimer's disease is the severe form of dementia, and the acetylcholinesterase (AChE) inhibitor drugs are used to treat Alzheimer's disease. Most of these drugs cause liver and bradycardia, intestine toxicities and stomach (Dökmeçi, 2000). The synthetic antioxidants can induce many side effects, for these reasons, the improvement and handling of safe anticholinesterases and antioxidants from nature are desired. As one of the most important secondary metabolites, phenolic compounds are widely investigated in many medicinal plants. The beneficial effects of phenolic compounds in human life is attributed to their antioxidant activity that mainly due to their redox 
properties, which allow them to act as reducing agents, hydrogen donators (Rice-Evans et al.,1996), radical scavengers, and metal chelators.

The relative or absolute deficiency of insulin or the resistance of the $\beta$ cells to the action of insulin causes an abnormal increase in the concentration of glucose in the blood that induces an endocrine disorder, it is the diabetes mellitus. The fast uptake of glucose in the intestine by the action of $\alpha$-amylase and $\alpha$-glucosidase helps in the breakdown of complex carbohydrates into simple sugars is an important factor which results in postprandial hyperglycemia (Nagmoti and Juvekar, 2013). The synthetic antidiabetic drugs are commonly used for treating diabetes mellitus by inhibiting $\alpha$-amylase and $\alpha$-glucosidase activity and thus, reduce glucose absorption in the body. These drugs can induce many side effects, such as renal tumors, adverse gastrointestinal symptoms and liver toxicity (Gray and Flatt, 1997; Fujisawa et al., 2005). For this reason, it is necessary to replace them with natural antidiabetic.

Plants from the genus Aloe belonging to Asparagaceae family have a long history of medicinal use in the treatment of many diseases. Among these plants we are interested by the Aloe vera which is an ornamental and medicinal plant, it is a perennial succulent plant. The leaves of Aloe vera consist of two products, first one is yellow bitter juice from cut leaf base and the second is mucilaginous juice from the leaf parenchyma. This plant has several biological properties: antimicrobial (Ferro et al., 2003; Cock, 2008), redox-state maintenance bioactivities (Sirdaarta and Cock, 2008; Sirdaarta and Cock, 2010), anti-diabetic, anti-inflammatory, anti-carcinogenic, anti-dermatological, nutritional, cosmetic, digestive (Hamman, 2008; Mariappan and Shanthi, 2012).

The major constituents of Aloe vera leaves can be classified into five groups, namely, phenolics, saccharides, vitamins, enzymes, and low molecular weight substances (Ray et al., 2013). A large part of the pharmacological properties are due to the presence of various polysaccharides and the phenolic compounds as well (Rodriguez et al., 2010). Aloe vera polysaccharides have also been speculated to enhance immunity activity and exert antioxidant effects in oral ulcer animal models (Yu et al., 2009). Faster wound closure has also been demonstrated in rats treated with isolated and characterised Aloe vera polysaccharides (Oryan et al., 2016). The biological activities of Aloe vera leaves is the results of synergism among the inherent component compounds of leaves, rather than a single ingredient (Hamman, 2008). The bioactivity of Aloe vera with reference to the anti-oxidative potential, has been demonstrated by different groups of authors, and the phenolic components and acetylated polysaccharides present in Aloe vera leaves have been assigned to the pertained free radical scavenging activities (Hu et al., 2003; Lui et al., 2007; El-Shemy et al., 2010; Ray et al., 2012). In our another investigation, it has been observed that the phenolic content, antioxidant, antidiabetic and anti-Alzheimer of Aloe vera are interlinked phenomena, and phenolic content was found to be critical in the regulation of pertained antioxidant activities, the antioxidant activity of aloin 
was also found to be significant in the investigation (Ray et al., 2012). Furthermore, Aloe vera leaves has shown its potential in the management of diabetes mellitus. Clinical trials have shown that, in obese individuals with prediabetes or early untreated diabetes mellitus, Aloe vera gel complex reduced body weight, body fat mass, and insulin resistance (Choi et al., 2013). Abo- Youssef and Messiha (2013) also proved the antidiabetic effect of Aloe vera leaf pulp extract in vivo and in vitro as compared to glimepiride.

The present study aims to determine the total polyphenol, flavonoid, flavonol, and tannin contents and to investigate the antioxidant, anti-Alzheimer and antidiabetic activities of different extracts and fractions of Aloe vera: methanol, chloroform, ethyl acetate, n-butanol, water and acetone.

\section{MATERIALS AND METHODS}

\section{Plant material}

The leaves of Aloe vera were collected in October 2016 from the Aloe vera farm at Paraje Retamar in the interior of the municipality of Almaria (southeast of Spain). The leaves of the plant were identified at the Laboratory of Functional and Evolutionary Ecology of Chadli Bendjedid University (El Tarf, Algeria), where the voucher specimen has been deposited. The leaves of the plant were crushed into a fine powder using an electric blender and then was stored in glass vials protected from light.

\section{Spectral measurements and chemicals used}

The measurements and calculations of the activity results were evaluated by using bioactivity measurements, they were carried out on a 96-well microplate reader, Perkin Elmer Multimode Plate Reader EnSpire at Center of Biotechnology Research. 1,1-diphenyl-2-picrylhydrazyl (DPPH), butylatedhydroxylanisole (BHA), butylatedhydroxyltoluene (BHT), $\alpha$ - Tocopherol, Folin-ciocalteu's reagent (FCR), 3-(2-Pyridyl)-5,6-di(2-furyl)-1,2,4-triazine-5',5"-disulfonic acid disodium salt (Ferrene), Ethylenediaminetetraacetic acid (EDTA), Neocuproine, 2,2'-azino-bis(3-ethylbenzothiazoline-6sulfonicacid)diammoniumsalt (ABTS), p-nitrophenyl- $\alpha$-D-glucopyranoside, 5,50-dithiobis (2-nitrobenzoic) acid (DTNB), acetylthiocholine iodide, butyrylthiocholine chloride, and galantamine were obtained from Sigma Chemical Co (Sigma-Aldrich GmbH, Stern-heim, Germany), horse serum butyrylcholinesterase (BChE, EC 3.1.1.8, 11.4 U/mg) and electric eel AChE (Type-VI-S, EC 3.1.1.7, 425.84 U/mg) were obtained from Sigma, St. Louis, MO, Copper (II) chloride, Potassium persulfate, Sodium Carbonate, Aluminum Nitrate, Iron (II) chloride, Potassium acetate, Ammonium acetate were obtained from Biochem Chemopharma. All other chemicals and solvents were of analytical grade. 


\section{Preparation and fractionation of methanolic extract}

The extraction was carried out according to the method of Yanlun et al. (2016) with minor modifications. $10 \mathrm{~g}$ of leaf powder was mixed with $100 \mathrm{~mL}$ of $\mathrm{MeOH} / \mathrm{H}_{2} \mathrm{O}(80: 20, \mathrm{v} / \mathrm{v})$ for $24 \mathrm{~h}$ at room temperature. The extraction was performed 3 times with renewal of the solvent. The contents were then filtered through Whatman filter paper $n^{\circ} 1$. The filtrate was evaporated at $40^{\circ} \mathrm{C}$ by a rotary evaporator. After evaporation, the obtained crude methanol extract was dissolved with $30 \mathrm{~mL}$ of water. The remaining solution was washed with $30 \mathrm{~mL}$ of petroleum ether to remove lipid soluble substances. Then the organic phase was eliminated. The remaining aqueous solution was successively extracted with chloroform, ethyl acetate and n-butanol. After evaporation, four fractions were obtained: chloroform, ethyl acetate, n-butanol and water.

\section{Preparation of acetone extract}

The preparation of the acetone extract was carried out according to the method of Zhang et al. (2008). $5 \mathrm{~g}$ of leaf powder was mixed with $100 \mathrm{~mL}$ of acetone and distilled water $(70 / 30, \mathrm{v} / \mathrm{v})$ for $72 \mathrm{~h}$ at room temperature. Then, the mixture was filtered through Whatman filter paper $n^{\circ} 1$. The filtrate was evaporated at $40^{\circ} \mathrm{C}$ by a rotary evaporator. The remaining solution was washed with $30 \mathrm{~mL}$ of dichloromethane to remove lipid soluble substances. The aqueous phase was extracted with $30 \mathrm{~mL}$ of ethyl acetate. After evaporation of the solvent, the acetone extract was obtained.

The extraction yield was calculated and expressed as the percentage of the extract in relation to the mass of crushed leaves $(\%, w / w)$.

\section{Determination of total polyphenol content}

The TPC of extracts and fractions was determined on the microplate reader according to a method described by Müller et al. (2010). A volume of $20 \mu \mathrm{L}$ of extract solution $(1 \mathrm{mg} / \mathrm{ml}$ in methanol) was mixed with $100 \mu \mathrm{L}$ of FolinCiocalteu reagent $(1: 10)$ and $75 \mu \mathrm{L}$ of sodium carbonate $7.5 \%$. The mixture was incubated at room temperature in the dark for $2 \mathrm{~h}$. A blank is prepared in the same way by replacing the extract by the used solvent. The absorbance was read at 765 $\mathrm{nm}$ using a 96-well microplate reader. The TPC was calculated from the linear regression equation of standard curve of gallic acid $\left(y=0.003 x+0.104, R^{2}=0.997\right)$ and expressed as gallic acid equivalents in micrograms per milligram of extract ( $\mu \mathrm{g} \mathrm{GAE} / \mathrm{mg}$ extract).

\section{Determination of total flavonoid content}

The TFC was determined using the aluminum chloride $\left(\mathrm{AlCl}_{3}\right)$ method developed by Topçu et al. (2007) with some modifications. A volume of $50 \mu \mathrm{L}$ of extract solution $(1 \mathrm{mg} / \mathrm{ml}$ in methanol) was mixed with $30 \mu \mathrm{L}$ of methanol, $10 \mu \mathrm{L}$ of potassium acetate $(1 \mathrm{M})$ and $10 \mu \mathrm{L}$ of aluminium nitrate $(10 \%)$. The mixture was allowed to stand at room temperature for $40 \mathrm{~min}$. A blank is prepared in the same way by replacing the extract by the used solvent. The absorbance was read at $415 \mathrm{~nm}$ using a 96-well microplate reader. The TFC was calculated 
from the linear regression equation of standard curve of quercetin $(\mathrm{y}=0.004 \mathrm{x}$, $\mathrm{R}^{2}=0.997$ ) and expressed as quercetin equivalents in micrograms per milligram of extract ( $\mu \mathrm{g} \mathrm{QE} / \mathrm{mg}$ extract).

\section{Determination of total flavonol content}

The FLC was determined using the aluminum chloride $\left(\mathrm{AlCl}_{3}\right)$ method developed by Kumaran and Karunakaran (2007). $50 \mu \mathrm{L}$ of extract solution (1 $\mathrm{mg} / \mathrm{ml}$ in methanol) was mixed with $50 \mu \mathrm{L}(20 \mathrm{mg} / \mathrm{mL})$ aluminum chloride and $150 \mu \mathrm{L}(50 \mathrm{mg} / \mathrm{mL})$ sodium acetate. The mixture was incubated for $150 \mathrm{~min}$ at room temperature in the dark, the absorbance was measured at $440 \mathrm{~nm}$ using a 96-well microplate reader. The FLC was calculated from the linear regression equation of standard curve of quercetin $\left(y=0.012 x+0.017, R^{2}=0.999\right)$ and expressed as quercetin equivalents in micrograms per milligram of extract ( $\mu \mathrm{g} \mathrm{QE} / \mathrm{mg}$ extract).

\section{Determination of total condensed Tannins content}

The TCTC was determined using the vanillin assay (Julkunen-Titto, 1985). To $50 \mu \mathrm{L}$ of sample, $1,500 \mu \mathrm{L}$ of vanillin/methanol solution $(4 \%$, w/v) were added, and the solution was homogenized. Then, $750 \mu \mathrm{L}$ of concentrated $\mathrm{HCl}$ were added and left at room temperature around $20 \mathrm{~min}$. The absorbance was measured against the blank at $550 \mathrm{~nm}$. The TCTC was calculated from the linear regression equation of standard curve of catechin $\left(\mathrm{y}=0.004 \mathrm{x}-0.038, \mathrm{R}^{2}=0.994\right)$ and expressed as catechin equivalents micrograms per milligram of extract ( $\mu \mathrm{g} \mathrm{CE} / \mathrm{mg}$ Extract).

\section{Determination of total hydrolysable Tannins content}

The THTC was determined using potassium iodate assay (Çam and Hişil, 2010). A volume of $1 \mathrm{~mL}$ of sample was mixed with $5 \mathrm{~mL}$ of the potassium iodate $(4 \%)$, the mixture was homogenized and left at room temperature around $15 \mathrm{~min}$. The absorbance was measured against the blank at 550. The THTC was calculated from the linear regression equation of standard curve of tannic acid $\left(\mathrm{y}=0.144 \mathrm{x}-0.133, \mathrm{R}^{2}=0.989\right)$ and expressed as tannic acid equivalents micrograms per milligram of extract ( $\mu \mathrm{g} \mathrm{TAE} / \mathrm{mg}$ Extract).

\section{Antioxidant activity}

DPPH free radical scavenging activity. The free radical scavenging activity of the extracts, fractions and standards (BHT, BHA and $\alpha$ tocopherol) was determined spectrophotometrically by the DPPH assay described by Blois (1958) with slight modifications. $40 \mu \mathrm{L}$ of various concentrations (12.5-800 $\mu \mathrm{g} / \mathrm{mL}$ ) was added to $160 \mu \mathrm{L}$ of freshly prepared DPPH solution $(0.1 \mathrm{M})$ in methanol. The mixture was incubated for $30 \mathrm{~min}$ at room temperature in the dark, the absorbance was measured at $517 \mathrm{~nm}$ using a 96-well microplate reader. BHT, BHA and $\alpha$-tocopherol were used as antioxidant standards for comparison of the activity. 
DPPH free radical scavenging activity in percentage (\%) was calculated using the following equation :

$$
\% \text { Inhibition }=\left[\left(\mathrm{Abs}_{\mathrm{CN}}-\mathrm{Abs}_{\mathrm{Ext}}\right) / \mathrm{Abs}_{\mathrm{CN}}\right] \times 100
$$

Where $\mathrm{Abs}_{\mathrm{CN}}$ is the absorbance of the control reaction and $\mathrm{Abs}_{\mathrm{Ext}}$ is the absorbance of the extract.

ABTS cation radical decolorization assay. The $\mathrm{ABTS}^{+}$scavenging activity was done by the method of Re et al. (1999) with slight modifications. The ABTS $^{+}$was produced by the reaction between $7 \mathrm{mM}$ ABTS in distilled water and $2.45 \mathrm{mM}$ potassium persulfate, stored in the dark at room temperature for $12 \mathrm{~h}$. The ABTS ${ }^{++}$solution was diluted to get an absorbance of $0.703 \pm 0.025$ at $734 \mathrm{~nm}$ with ethanol. $40 \mu \mathrm{L}$ of various concentrations $(12.5-800 \mu \mathrm{g} / \mathrm{mL})$ was added to $160 \mu \mathrm{L}$ of $\mathrm{ABTS}^{++}$solution, After $10 \mathrm{~min}$ the absorbance was measured at 734 $\mathrm{nm}$ using a 96-well microplate reader. BHTand BHA were used as antioxidant standards for comparison of the activity. The scavenging capability of ABTS·+ was calculated using the following equation :

$$
\% \text { Inhibition }=\left[\left(\mathrm{Abs}_{\mathrm{CN}}-\mathrm{Abs}_{\mathrm{Ext}}\right) / \mathrm{Abs}_{\mathrm{CN}}\right] \times 100
$$

Where $\mathrm{Abs}_{\mathrm{CN}}$ is the absorbance of the control reaction and $\mathrm{Abs}_{\mathrm{Ext}}$ is the absorbance of the extract. The results were given as $\mathrm{IC}_{50}$ value $(\mu \mathrm{g} / \mathrm{mL})$ corresponding the concentration of 50\% inhibition.

Cupric reducing antioxidant capacity assay. The cupric reducing antioxidant capacity of the extracts and fractions was determined by the CUPRAC method (Apak et al., 2004) with slight modifications. $40 \mu \mathrm{L}$ of various concentrations $(12.5-800 \mu \mathrm{g} / \mathrm{mL})$ was added to $60 \mu \mathrm{L}$ of Ammonium Acetate buffer (1 M, PH 7.0) solution, $50 \mu \mathrm{L}$ of copper (II) chloride solution $(0.01 \mathrm{M}$ prepared from $\left.\mathrm{CuCl}_{2}, 2 \mathrm{H}_{2} \mathrm{O}\right)$ and $50 \mu \mathrm{L}$ of neocaproine solution $(0.0075 \mathrm{M})$. The mixture was incubated for $60 \mathrm{~min}$ at room temperature. The absorbance of the solution was measured at $450 \mathrm{~nm}$ by the use of 96-well microplate reader. BHT, BHA and $\alpha$-tocopherol were used as antioxidant standards for comparison of the activity. The results were given as $A_{0.50}(\mu \mathrm{g} / \mathrm{mL})$ corresponding the concentration indicating 0.50 absorbance intensity.

Metal chelating activity on ferrous ions. The metal chelating activity of Aloe vera extracts and fractions on $\mathrm{Fe}^{2+}$ was measured spectrophotometrically (Decker and Welch, 1990) with slight modifications. $40 \mu \mathrm{L}$ of various concentrations $(12.5-800 \mu \mathrm{g} / \mathrm{mL})$ was added to $40 \mu \mathrm{L}$ of methanol and $40 \mu \mathrm{L}$ of $0.2 \mathrm{mM} \mathrm{FeCl}_{2}$. The reaction was initiated by the addition of $80 \mu \mathrm{L} 0.5 \mathrm{mM}$ ferene, after 10 min the absorbance was measured at $593 \mathrm{~nm}$ using a 96-well microplate reader. EDTA was used as chelating standard for comparison of the activity. 
The metal chelating activity was calculated using the following equation. The results were given as $\mathrm{IC}_{50}(\mu \mathrm{g} / \mathrm{mL})$ :

$$
\% \text { Inhibition }=\left[\left(\mathrm{Abs}_{\mathrm{CN}}-\mathrm{Abs}_{\mathrm{Ext}}\right) / \mathrm{Abs}_{\mathrm{CN}}\right] \times 100
$$

Where $\mathrm{Abs}_{\mathrm{CN}}$ is the absorbance of the control reaction and $\mathrm{Abs}_{\mathrm{Ext}}$ is the absorbance of the extract.

\section{Anti-Alzheimer activity}

Acetylcholinesterase (AChE) and butyrylcholinesterase (BChE) inhibitory activities of the extracts and fractions was determined by the method of Ellman et al. (1961) with slight modifications. $150 \mu \mathrm{L}$ of sodium phosphate buffer $(100$ $\mathrm{mM}, \mathrm{pH} 8.0), 10 \mu \mathrm{L}$ of the sample solution dissolved in ethanol at different concentrations $(3.125-200 \mu \mathrm{g} / \mathrm{mL})$ and $20 \mu \mathrm{L}$ AChE or BChE solution in buffer were mixed and incubated for $15 \mathrm{~min}$ at $25{ }^{\circ} \mathrm{C}$, and $10 \mu \mathrm{L}$ of DTNB $(0.5 \mathrm{mM})$ was added. The reaction was then initiated by the addition of $10 \mu \mathrm{L}$ of acetylthiocholine iodide $(0.5 \mathrm{mM})$ or $10 \mu \mathrm{L}$ of butyrylthiocholine chloride $(0.2 \mathrm{mM})$. The absorbance of the solution was measured at $412 \mathrm{~nm}$ by the use of 96-well microplate reader. The galantamine was used as the reference compound. The results were given as $\mathrm{IC}_{50}$ value $(\mu \mathrm{g} / \mathrm{mL})$ corresponding the concentration of $50 \%$ inhibition.

\section{Antidiabetic activity}

Alpha-glucosidase inhibition assay. Alpha-glucosidase inhibitory activity was performed according to Nampoothiri et al. (2011). $50 \mu \mathrm{L}$ of various concentrations $(15.62-1000 / \mathrm{mL})$ was added to $100 \mu$ l of enzyme solution $(0.1 \mathrm{U} / \mathrm{ml})$ and $50 \mu \mathrm{l}$ substrate solution (using $5 \mathrm{mM}$ p-nitrophenyl- $\alpha$-Dglucopyranoside in $100 \mathrm{mM}$ sodium phosphate buffer, $\mathrm{pH}$ 6.9). The mixture was incubated for $5 \mathrm{~min}$ at $37^{\circ} \mathrm{C}$, the absorbance was measured at $405 \mathrm{~nm}$ each 10 $\mathrm{min}$, for $30 \mathrm{~min}$ using a 96-well microplate reader. Acarbose $(1 \mathrm{mg} / \mathrm{ml})$ was used as a positive control. The results were given as $\mathrm{IC}_{50}$ value $(\mathrm{mg} / \mathrm{mL})$ corresponding to the concentration shows $50 \%$ inhibition.

\section{Statistical analysis}

All assays were estimated in triplicates and the results were presented as means \pm standard deviation (SD). Statistical analysis was performed using Variance Analysis (ANOVA). The results are considered to be significant when $P<0.05$.

\section{RESULTS}

\section{Extraction yield}

The extraction yield was calculated for the different extracts and fractions of Aloe vera. The highest yield was $20 \%$ for methanolic extract while its fractions; chloroform, ethyl acetate, n-butanol, water were $3.50 \%, 1.35 \%, 14.63 \%, 12.72 \%$ 
respectively. It was noted that the acetone extract has the low yield $1.16 \%$. These results are presented in Table 1.

Table 1. Extraction yields of Aloe vera in the organic solvents.

\begin{tabular}{lc}
\hline Extracts/ Fractions & Yields (\%) \\
\hline Methanol & $20.97 \pm 0.36$ \\
Chloroform & $3.50 \pm 0.11$ \\
Ethyl acetate & $1.35 \pm 0.12$ \\
n-Butanol & $14.63 \pm 0.12$ \\
Water & $12.72 \pm 0.75$ \\
Acetone & $1.16 \pm 0.5$ \\
\hline
\end{tabular}

\section{Total polyphenol, total flavonoid, total flavonol, total condensed and total hydrolysable tannin contents}

The quantification of TPC, TFC, FLC, TCTC and THTC of Aloe vera extracts and fractions are presented in Table 2. The total phenol content was significantly $(P<0.05)$ higher than total flavonoid and total flavonol. The ethyl acetate fraction showed the highest TPC (258.78 $\mu \mathrm{g}$ GAE/mg extract) followed by acetone extract ( $225.33 \mu \mathrm{g} \mathrm{GAE} / \mathrm{mg}$ extract), chloroform (199.89 $\mu \mathrm{g}$ GAE/mg extract), methanol (187.55 $\mu \mathrm{g}$ GAE/mg extract) and n-butanol (149.22 $\mu \mathrm{g}$ $\mathrm{GAE} / \mathrm{mg}$ extract). Whereas, the water fraction showed the lowest level (125.67 $\mu \mathrm{g}$ GAE/mg extract). While, for the TFC, the acetone extract was found to have the highest TFC (175.58 $\mu \mathrm{g} \mathrm{QE} / \mathrm{mg}$ extract) compared to chloroform fraction (90.25 $\mu \mathrm{g} \mathrm{QE} / \mathrm{mg}$ extract), n-butanol fraction (77.5 $\mu \mathrm{g} \mathrm{QE} / \mathrm{mg}$ extract), methanolic extract (76.25 $\mu \mathrm{g}$ QE/mg extract) and water fraction $(75.75 \mu \mathrm{g} \mathrm{QE} / \mathrm{mg}$ extract). However, the lower rate of TFC was found in the ethyl acetate fraction $(67 \mu \mathrm{g} \mathrm{QE} / \mathrm{mg}$ extract).

The acetone extract exhibited the highest FLC with $(87.30 \mu \mathrm{g}$ QE/mg extract) followed by ethyl acetate, chloroform, methanol, n-butanol and water extracts $(50.13 \mu \mathrm{g} \mathrm{QE} / \mathrm{mg}$ extract, $39.69 \mu \mathrm{g} \mathrm{QE} / \mathrm{mg}$ extract, $39.58 \mu \mathrm{g} \mathrm{QE} / \mathrm{mg}$ extract, $32.38 \mu \mathrm{g} \mathrm{QE} / \mathrm{mg}$ extract and $27.86 \mu \mathrm{g} \mathrm{QE} / \mathrm{mg}$ extract respectively).

The TCTC of extracts and fractions ranged from 11.66 to $38.16 \mu \mathrm{g} \mathrm{CE} / \mathrm{mg}$ extract. This study showed that the acetone extract of leaves exhibited the highest TCTC with (38.16 $\mu \mathrm{g} \mathrm{CE} / \mathrm{mg}$ extract) followed by ethyl acetate, methanol, chloroform, n-butanol and water extracts $(36.66 \mu \mathrm{g} \mathrm{CE} / \mathrm{mg}$ extract, $19.41 \mu \mathrm{g}$ $\mathrm{CE} / \mathrm{mg}$ extract, $16.83 \mu \mathrm{g} \mathrm{CE} / \mathrm{mg}$ extract, $13.41 \mu \mathrm{g} \mathrm{CE} / \mathrm{mg}$ extract and $11.66 \mu \mathrm{g}$ $\mathrm{CE} / \mathrm{mg}$ extract respectively). The THTC varied from 0.94 to $1.22 \mu \mathrm{g}$ TAE/mg extract. Among the extracts, the water fraction was found to contain the highest amount of THTC $(1.22 \mu \mathrm{g}$ TAE/mg extract). 
Table 2. Total polyphenol, total flavonoid, total flavonol, total condensed tannin and total hydrolysable tannin contents of Aloe vera extracts and fractions.

\begin{tabular}{lccccc}
\hline $\begin{array}{l}\text { Extracts/ } \\
\text { Fractions }\end{array}$ & TPC $^{\mathbf{1}}$ & TFC $^{\mathbf{2}}$ & FLC $^{\mathbf{3}}$ & TCTC $^{\mathbf{4}}$ & THTC $^{\mathbf{5}}$ \\
\hline Methanol & $187.55 \pm 0.09$ & $76.25 \pm 0.03$ & $39.58 \pm 0.88$ & $19.41 \pm 0.76$ & $0.94 \pm 0.01$ \\
Chloroform & $199.89 \pm 0.04$ & $90.25 \pm 0.00$ & $39.69 \pm 0.01$ & $16.83 \pm 0.38$ & $1.02 \pm 0.00$ \\
Ethyl acetate & $225.33 \pm 0.05$ & $67 \pm 0.04$ & $50.13 \pm 0.02$ & $36.66 \pm 0.62$ & $1.04 \pm 0.02$ \\
n-Butanol & $149.22 \pm 0.00$ & $77.5 \pm 0.01$ & $32.38 \pm 0.00$ & $13.41 \pm 0.46$ & $0.97 \pm 0.01$ \\
Water & $125.67 \pm 0.2$ & $75.75 \pm 0.16$ & $27.86 \pm 0.25$ & $11.66 \pm 0.14$ & $1.22 \pm 0.02$ \\
Acetone & $258.78 \pm 0.09$ & $175.58 \pm 0.02$ & $87.30 \pm 0.01$ & $38.16 \pm 0.87$ & $1.00 \pm 0.04$ \\
\hline
\end{tabular}

Note: Each value represents a means \pm SD of three parallel measurements $(P<0.05) .{ }^{1}: \mu \mathrm{g}$ gallic acid/mg Extract,

${ }^{2}: \mu \mathrm{g}$ quercetin/mg Extract, ${ }^{3}: \mu \mathrm{g}$ quercetin/mg Extract, ${ }^{4}: \mu \mathrm{g}$ catechin $/ \mathrm{mg}$ Extract, ${ }^{5}: \mu \mathrm{g}$ tannic acid $/ \mathrm{mg}$ extract.

\section{Antioxidant activities}

The free radical scavenging activity of extracts and fractions is presented in Table 3. The results reveal that the $\mathrm{DPPH}^{*}$ Radical scavenging activity increased linearly with increasing of concentration. In this study The methanolic extract exhibited the highest activity $\left(\mathrm{IC}_{50}: 24.21 \mu \mathrm{g} / \mathrm{mL}\right)$ in comparison with the other extracts and closer activity to that of BHT $\left(\mathrm{IC}_{50}: 12.99 \mu \mathrm{g} / \mathrm{mL}\right.$ ), $\alpha$-Tocopherol $\left(\mathrm{IC}_{50}: 13.03 \mu \mathrm{g} / \mathrm{mL}\right.$ ), and further to the BHA ( $\mathrm{IC}_{50}: 6.15 \mu \mathrm{g} / \mathrm{mL}$ ), followed by acetone extract, n-butanol, ethyl acetate and chloroform fractions ( $\mathrm{IC}_{50}$ : 92.20, 119.63, 297.15, $298.20 \mu \mathrm{g} / \mathrm{mL}$, respectively). The methanolic extract also exhibited a good activity but less than those of antioxidant standards, however Water fraction showed weak activity $\left(\mathrm{IC}_{50}>800 \mu \mathrm{g} / \mathrm{mL}\right)$.

The results of ABTS Radical Scavenging Assay of the extracts and fractions are compared with those of BHT and BHA (Table 3). The methanolic extract exhibited the highest activity $\left(\mathrm{IC}_{50}: 30.75 \mu \mathrm{g} / \mathrm{mL}\right)$ ) very close to the n-butanol fraction and water fraction ( $\mathrm{IC}_{50}: 34.16$ and $37.60 \mu \mathrm{g} / \mathrm{mL}$, respectively) and is further to BHA and BHT ( $\mathrm{IC}_{50}: 1.82$ and $1.30 \mu \mathrm{g} / \mathrm{mL}$, respectively), followed by chloroform fraction $\left(\mathrm{IC}_{50}: 42.14 \mu \mathrm{g} / \mathrm{mL}\right.$ ) and acetone exract $\left(\mathrm{IC}_{50}: 81.84 \mu \mathrm{g} / \mathrm{mL}\right)$, these last extracts and fractions also exhibited a good activity but less than those of antioxidant standards, however the ethyl acetate showed weak activity $\left(\mathrm{IC}_{50}: 128.98 \mu \mathrm{g} / \mathrm{mL}\right)$.

The results of CUPRAC of the extracts and fractions are compared with those of BHT and BHA (Table 3). Activity (absorbance) increased linearly with the increasing amount of extracts and fractions. In this assay the methanolic extract exhibited highest activity $\left(\mathrm{A}_{0.50}: 17.50 \mu \mathrm{g} / \mathrm{mL}\right)$ among the extracts, followed by acetone extract $\left(\mathrm{A}_{0.50}: 22.82 \mu \mathrm{g} / \mathrm{mL}\right)$, ethyl acetate fraction $\left(\mathrm{A}_{0.50}\right.$ : 
$41.09 \mu \mathrm{g} / \mathrm{mL})$, n-butanol fraction $\left(\mathrm{A}_{0.50}: 158 \mu \mathrm{g} / \mathrm{mL}\right)$, water $\left(\mathrm{A}_{0.50}: 162.50\right.$ $\mu \mathrm{g} / \mathrm{mL})$ and chloroform $\left(\mathrm{A}_{0.50}: 172.50 \mu \mathrm{g} / \mathrm{mL}\right)$. However, none of the extracts exhibited higher activity than those of antioxidant standards.

The chelating effect of the extracts and fractions on ferrous ions is shown in Table 3, compared with EDTA. The methanolic extract also showed the highest metal chelating activity $\left(\mathrm{IC}_{50}: 140.99 \mu \mathrm{g} / \mathrm{mL}\right)$ followed by chloroform fraction $\left(\mathrm{IC}_{50}: 156.17 \mu \mathrm{g} / \mathrm{mL}\right.$ ), water fraction $\left(\mathrm{IC}_{50}: 165.38 \mu \mathrm{g} / \mathrm{mL}\right)$, n-butanol fraction $\left(\mathrm{IC}_{50}: 220.87 \mu \mathrm{g} / \mathrm{mL}\right)$, ethyl acetate fraction $\left(\mathrm{IC}_{50}: 545.31 \mu \mathrm{g} / \mathrm{mL}\right)$ and acetone extract $\left(\mathrm{IC}_{50}>800 \mu \mathrm{g} / \mathrm{mL}\right)$.

Table 3. Antioxidant activity of Aloe vera extracts and fractions by DPPH, ABTS, CUPRAC and metal chelating assays.

\begin{tabular}{lcccc}
\hline $\begin{array}{l}\text { Extracts/ } \\
\text { Fractions }\end{array}$ & $\begin{array}{c}\text { DPPH assay } \\
\mathbf{I C}_{\mathbf{5 0}}(\boldsymbol{\mu g} / \mathbf{m l})\end{array}$ & $\begin{array}{c}\text { ABTS assay } \\
\mathbf{I C}_{\mathbf{5 0}}(\boldsymbol{\mu g} / \mathbf{m l})\end{array}$ & $\begin{array}{c}\text { CUPRAC } \\
\text { assay } \\
\mathbf{A 0 . 5 0}(\boldsymbol{\mu g} / \mathbf{m l})\end{array}$ & $\begin{array}{c}\text { Metal chelate assay } \\
\mathbf{I C}_{\mathbf{5 0}}(\boldsymbol{\mu g} / \mathbf{m l})\end{array}$ \\
\hline Methanol & $24.21 \pm 0.30$ & $30.75 \pm 1.67$ & $17.50 \pm 0.47$ & $140.99 \pm 2.95$ \\
Chloroform & $298.20 \pm 1.54$ & $42.14 \pm 0.66$ & $172.50 \pm 2.12$ & $156.17 \pm 1.85$ \\
Ethyl acetate & $297.15 \pm 4.84$ & $128.98 \pm 1.62$ & $41.09 \pm 1.29$ & $545.31 \pm 2.21$ \\
n-Butanol & $119.63 \pm 0.23$ & $34.16 \pm 0.64$ & $158 . \pm 2.83$ & $220.87 \pm 1.76$ \\
Water & $>800$ & $37.60 \pm 0.67$ & $162.50 \pm 0.71$ & $165.38 \pm 0.31$ \\
Acetone & $92.20 \pm 7.09$ & $81.84 \pm 0.39$ & $22.82 \pm 2.47$ & $>800$ \\
BHA $^{\mathrm{a}, \mathrm{b}}$ & $6.15 \pm 0.42$ & $1.82 \pm 0.11$ & $5.35 \pm 0.71$ & $\mathrm{NT}^{\mathrm{e}}$ \\
BHT $^{\mathrm{a}, \mathrm{c}}$ & $12.99 \pm 0.45$ & $1.30 \pm 0.31$ & $8.97 \pm 3.94$ & $\mathrm{NT}^{\mathrm{e}}$ \\
$\alpha-$ Tocopherol $^{\mathrm{a}}$ & $13.03 \pm 5.20$ & $\mathrm{NT}^{\mathrm{e}}$ & $\mathrm{NT}^{\mathrm{e}}$ & $\mathrm{NT}^{\mathrm{e}}$ \\
EDTA $^{\mathrm{a}, \mathrm{d}}$ & $\mathrm{NT}$ & $\mathrm{NT}^{\mathrm{e}}$ & $\mathrm{NT}^{\mathrm{e}}$ & $8.80 \pm 0.47$ \\
\hline
\end{tabular}

Note: $\mathrm{IC}_{50}$ and $\mathrm{A}_{0.50}$ values represent the means $\pm \mathrm{SD}$ of three parallel measurements $(P<0.05)$.

${ }^{\mathrm{a}}$ Reference compounds, ${ }^{\mathrm{b}}$ Butylatedhydroxyanisole, ${ }^{\mathrm{c}}$ Butylatedhydroxyltoluene,

${ }^{\mathrm{d}}$ Ethylenediaminetetraacetic acid, ${ }^{\mathrm{e}}$ Not tested.

\section{Anti-Alzheimer activity}

Table 4 shows the AChE and BChE inhibitory activities of the extracts and fractions of Aloe vera, compared with that of galantamine. The n-butanol and chloroform fractions exhibited moderate $\mathrm{BChE}$ inhibitory activity $\left(\mathrm{IC}_{50}\right.$ value: $79.61 \pm 2.41$ and $94.04 \pm 1.41 \mu \mathrm{g} / \mathrm{mL}$, respectively) but this BChE inhibitory activity is lower than the galantamine standard $\left(\mathrm{IC}_{50}\right.$ value : $34.75 \pm 1.99 \mu \mathrm{g} / \mathrm{mL}$ ), whilst they showed mild AChE inhibitory activity. However, acetone extract showed weak inhibitory activity against $\mathrm{BChE}\left(\mathrm{IC}_{50}\right.$ value : $\left.102.32 \pm 0.24 \mu \mathrm{g} / \mathrm{mL}\right)$. Methanolic extract, acetate ethyl and water fractions showed mild BChE inhibitory activity, whilst they exhibited no activity against AChE enzyme. 
Table 4. Acetylcholinesterase and butyrylcholinesterase inhibitory activities of Aloe vera extracts and fractions.

\begin{tabular}{lcc}
\hline Extracts/Fractions & $\begin{array}{c}\text { AChE assay } \\
\mathbf{I C}_{\mathbf{5 0}}(\boldsymbol{\mu} \mathbf{g} / \mathbf{m L})\end{array}$ & $\begin{array}{c}\text { BChE assay } \\
\mathbf{I C}_{\mathbf{5 0}}(\boldsymbol{\mu g} / \mathbf{m L})\end{array}$ \\
\hline Methanol & $\mathrm{NA}^{\mathrm{b}}$ & $>200$ \\
Chloroform & $>200$ & $94.04 \pm 1.41$ \\
Ethyl acetate & $\mathrm{NA}$ & $>200$ \\
n-Butanol & $>200$ & $79.61 \pm 2.41$ \\
Water & $\mathrm{NA}^{\mathrm{b}}$ & $>200$ \\
Acetone & $>200$ & $102.32 \pm 0.24$ \\
Galantamine & $6.27 \pm 1.15$ & $34.75 \pm 1.99$ \\
\hline
\end{tabular}

Note: $\mathrm{IC}_{50}$ values represent the means $\pm \mathrm{SD}$ of three parallel measurements $(P<0.05)$.

${ }^{\text {a }}$ Reference compounds, ${ }^{b}$ Not active.

\section{Antidiabetic activity}

Table 5 shows the $\alpha$-Glucosidase inhibitory activity of the extracts and fractions, compared with that of Acarbose used as a positive control. The n-butanol fraction ( $\mathrm{IC}_{50}$ value : $40.75 \pm 0.06 \mu \mathrm{g} / \mathrm{ml}$ ) exhibited highest $\alpha$ glucosidase inhibitory activity, even higher than Acarbose ( $\mathrm{IC}_{50}$ value : $151.30 \pm 0.08)$. Acetate ethyl fraction showed mild $\alpha$-Glucosidase Inhibitory activity $\left(\mathrm{IC}_{50}>1,000 \mu \mathrm{g} / \mathrm{mL}\right.$ ). The methanol extract, chloroform and aquous fractions, however, were inactive at all concentrations.

Table 5. $\alpha$-Glucosidase Inhibitory activity of Aloe vera extracts and fractions.

\begin{tabular}{|c|c|}
\hline Extracts/ Fractions & $\alpha$-Glucosidase Assay $\mathrm{IC}_{50}(\mu \mathrm{g} / \mathrm{mL})$ \\
\hline Methanol & $\mathrm{NA}^{\mathrm{b}}$ \\
\hline Chloroform & $\mathrm{NA}^{\mathrm{b}}$ \\
\hline Ethyl acetate & $>1,000$ \\
\hline n-Butanol & $40.75 \pm 0.06$ \\
\hline Water & $\mathrm{NA}^{\mathrm{b}}$ \\
\hline Acetone & $\mathrm{NA}^{\mathrm{b}}$ \\
\hline Acarbose $^{\mathrm{a}}$ & $156.17 \pm 1.85$ \\
\hline
\end{tabular}

Note: $\mathrm{IC}_{50}$ values represent the means $\pm \mathrm{SD}$ of three parallel measurements $(P<0.05)$.

${ }^{\mathrm{a}}$ Reference compounds, ${ }^{\mathrm{b}}$ Not active. 


\section{DISCUSSION}

The results of extraction yields are close to those of the work carried out by Saritha et al. (2010) who recorded an extraction yield equal to $28.14 \%$, and $3.05 \%$ for the methanol and chloroform extracts respectively. According to the results obtained by Ejoba (2012) they recorded an extraction yield of $8.6 \%$ for chloroform extract and $5.4 \%$ for the water extract. Concerning total polyphenol, flavonoid and flavonol contents, the results suggest that polyphenol, flavonoid and flavonol are important components of the crude methanolic extract. These results are in disagreement with The studies conducted by Anirban et al. (2013) which showed that the methanolic extract had values equal to $35.77 \mu \mathrm{g}$ GAE/mg extract, $29.75 \mu \mathrm{g} \mathrm{QE} / \mathrm{mg}$ extract, and $13.66 \mu \mathrm{g} \mathrm{QE} / \mathrm{mg}$ extract for total polyphenol, flavonoid and flavonol respectively. While, Taukoorah and Mahomoodally (2016) found that Aloe vera gave a value of $66.06 \mu \mathrm{g} \mathrm{GAE} / \mathrm{mg}$ extract for polyphenol and $60.95 \mu \mathrm{g} \mathrm{QE} / \mathrm{mg}$ extract for flavonoid. Several factors can influence the polyphenol and flavonoid contents such as the development period or the age of the plant (Okamura et al., 1996; Park and Kwon, 2006; Rodriguez et al., 2010). In term of DPPH-scavenging potential of methanolic extract, our results are in accordance with the studies carried out by Saritha et al. (2010), the inhibition percentages of methanolic, acetone and chloroform extracts were $93.14 \%, 74.03 \%, 57.68 \%$ respectively at $250 \mu \mathrm{g} / \mathrm{mL}$, in this studies the methanol extract showed better radical scavenging activity than the other extracts. Anirban et al. (2013) have also reported higher DPPH scavenging activities for methanolic extract $\left(\mathrm{IC}_{50} 58 \mu \mathrm{g} / \mathrm{mL}\right.$ ). This result is in agreement with the statement, Aloe vera extracted in different solvents obtained highest DPPH inhibition in methanol extract (Saritha et al., 2010). In the metal chelating activity on ferrous ions, the results of our investigation are in accordance with those published earlier, which mentioned that the methanolic extract showed more chelating ability than acetone extract of Aloe vera leaves. However, the chelating ability was relatively lower than that of EDTA (Saritha et al., 2010). The BChE inhibitory activity of chloroform extract may be due the presence of ursolic acid (Kolak et al., 2009) found in large amounts. The presence of flavonoids in the butanol extract may have caused BChE inhibitory activity.

In the present study, leaves of Aloe vera were assessed in terms of its ability to inhibit key carbohydrate hydrolysing enzymes. Significant inhibition was found explaining that the antidiabetic property of Aloe vera leaves may be due to enzyme inhibition. These results are in disagreement with The studies conducted by Taukoorah and Mahomoodally (2016), their results from $\alpha$-glucosidase inhibition assay showed no enzyme inhibitory activity for the Aloe vera leaves. Importantly, some researchers have indicated that there is a positive relationship between polyphenol content, total flavonoid and the ability to inhibit $\alpha$-Glucosidase (Ramkumar et al., 2010). The phenolic compounds are known by their capacity to inhibit the activities of carbohydrate-hydrolyzing enzymes 
because of their ability to bind to proteins (Shobana et al., 2009). Moreover, flavonoids have been known to possess high inhibitory potential towards $\alpha$-Glucosidase in both in vitro and in vivo studies (Adefegha and Oboh, 2012).

\section{CONCLUSION}

In this study, antioxidant, anti-Alzheimer and antidiabetic activities of leaves extracts and fractions of Aloe vera were determined. The methanolic extract exhibited the highest antioxidant activities in all assays. The n-butanol fraction indicated the highest BChE inhibitory activity and the good $\alpha$-glucosidase inhibitory activity.

These results showed that Aloe vera would be suggested as a new potential source of natural antioxidative phenolic compounds, which can replace the synthetic antioxidant in the field of cosmetics, pharmaceuticals and foods. In addition, the results revealed that the leaves of Aloe vera can be exploited in the discovery of bioactive natural products for the treatment of diabetes mellitus and Alzheimer's disease. However, this study can be complemented by isolation and identification of several polyphenolic components for a therapeutic purpose.

\section{ACKNOWLEDGEMENTS}

The authors wish to express thanks to Algerian minister of higher education and scientific research (MESRS) for the support, to Mr. Manuel Navarro (Agricultural engineer, Owner of Aloe vera farm in Almaria, Spain) for the harvest of plant, Mr. Bouhedjar Khalid (Biotechnology Research Center, Constantine, Algeria.) for the statistical analysis.

\section{REFERENCES}

Abo-Youssef, A.M.H., and Messiha, B.A. 2013. Beneficial effects of Aloe vera in treatment of diabetes: comparative in vivo and in vitro studies. Bulletin of Faculty of Pharmacy, Cairo University. 51(1): 7-11. https://doi.org/ 10.1016/j.bfopcu.2012.03.002

Adefegha, S.A.A., and Oboh, G. 2012. In vitro inhibition activity of polyphenolrich extracts from Syzygium aromaticum (L.) Merr. \& Perry (Clove) buds against carbohydrate hydrolyzing enzymes linked to type 2 diabetes and $\mathrm{Fe}^{2+}$-induced lipid peroxidation in rat pancreas. Asian Pacific Journal of Tropical Biomedicine. 2(10): 774-781. https://doi.org/10.1016/S22211691(12)60228-7

Anirban, R., Dutta Gupta, S., and Sampad, G. 2013. Evaluation of anti oxidative activity and UV absorption potential of the extracts of Aloe vera L. gel from different growth periods of plants. Industrial Crops and Products. 49: 712-719. https://doi.org/10.1016/j.indcrop.2013.06.008 
Apak, R., Gü̈lü, K., Özyürek, M., and Karademir, S.E. 2004. Novel total antioxidant capacity index for dietary polyphenols and vitamins $\mathrm{C}$ and $\mathrm{E}$, using their cupricion reducing capability in the presence of neocuproine: CUPRAC method. Journal of Agricultural and Food Chemistry. 52(26): 7970-7981. https://doi.org/10.1021/jf048741x

Blois, M.S.1958. Antioxidant determinations by the use of a stable free radical. Nature.181: 1199-1200. https://doi.org/10.1038/1811199a0

Çam, M., and Hişil, Y. 2010. Pressurised water extraction of polyphenols from pomegranate peels. Food Chemical. 123(3): 878-885. https://doi.org/10. 1016/j.foodchem.2010.05.011

Choi, H.C., Kim, S.J., Son, K.Y, Oh, B.J., and Cho, B.L. 2013. Metabolic effects of aloe vera gel complex in obese prediabetes and early non-treated diabetic patients: randomized controlled trial. Nutrition. 29(9): 1110-1114. https://doi.org/10.1016/j.nut.2013.02.15

Cock, I.E. 2008. Antimicrobial activity of Aloe barbadensis Miller leaf gel components. Journal of Microbiology. 4: 2.

Decker, E.A., and Welch, B. 1990. Role of ferritin as a lipid oxidation catalyst in muscle Journal of Agricultural and Food Chemistry. 38(3): 674-677. https://doi.org/10.1021/jf00093a019

Dökmeçi, I. 2000. Fundamentals of Pharmacology. Istanbul, Turkey: Nobel Tip Kitabevi Press.

Ejoba, R. 2012 Phytochemical constituents of some leaves extract of Aloe vera and Azadirachta indica plant species. Global Advanced Research Journal of Environmental Science and Toxicology. 1(2): 014-017

El-Shemy, H., Aboul-Soud, M.A., Aboul-Enein, K.M., Kabash, A., and Yagi, A. 2010. Anti-tumor properties and modulation of antioxidant enzymes activity by Aloe veraleaf active principles isolated via supercritical carbon dioxide extraction. Current Medicinal Chemistry. 17(2): 129-138. https:// doi.org/10.2174/092986710790112620

Ellman, G.L., Courtney, K.D., Andres, V., and Featherston, R.M. 1961. A new and rapid colorimetric determination of acetylcholinesterase activity. Biochemical Pharmacology. 7: 88-95. https://doi.org/10.1016/0006-2952 (61)90145-9

Ferro, V.A., Bradbury, F., Cameron, P., Shakir, E., Rahman, S.R., and Stimson, W.H. 2003. In vitro susceptibilities of Shigella flexneri and Streptococcus pyogenes to inner gel of Aloe barbadensis Miller. Antimicrobial Agents and Chemotherapy. 47(3): 1137-1139. https://doi. org/10.1128/AAC.47.3.1137-1139.2003

Fujisawa, T., Ikegami, H., Inoue, K., Kawabata, Y., and Ogihara, T. 2005. Effect of two $\alpha$-glucosidase inhibitors, voglibose and acarbose, on postprandial hyperglycemia correlates with subjective abdominal symptoms. Metabolism. 54(3): 387-390. https://doi.org/10.1016/j.metabol.2004.10.004 
Gilani A.H., and Rahman A.U. 2005. Trends in ethnopharmocology. Journal of Ethnopharmacology. 100(1-2): 43-49. https://doi.org/10.1016.j.jep.2005. 06.001

Gray, M., and Flatt, R. 1997. Nature's own pharmacy: the diabetes perspective. Proceedings of the Nutrition Society. 56: 507-517. https://doi.org/10.1079/ PNS19970051

Halliwell, B. 1999. Establishing the significance and optimal intake of dietary antioxidants: the biomarker concept. Nutrition Reviews. 57(4): 104-113. https://doi.org/10.1111/j.1753-4887.1999.tb06933.x

Hamman, J.H. 2008 Composition and applications of Aloe vera leaf gel. Molecules. 13(8): 1599-1616. https://doi.org/10.3390.molecules13081599

Hoareau, L., and Dasilva E.J. 1999. Medicinal plants: a re-emerging health aid. Electronic Journal of Biotechnology. 2(2): 3-4.

Hostettmann, K., and Hamburger M. 1993. Search for new lead compounds of natural origin. In: Testa, B., Kyburz, E., Fuhrer, W., Giger, R., editors. Perspectives in Medical Chemistry. Verlag Helvitica Acta, Basel.

Hu, Y., Xu, J., and Hu, Q. 2003. Evaluation of antioxidant potential of Aloe vera (Aloe barbadensis Miller) extracts. Journal of Agricultural and Food Chemistry. 51(26): 7788-7791. https://doi.org/10.1021/jf034255i

Julkunen-Titto, R. 1985. Phenolic constituents in the leaves of northern Willows methods for the analysis of certain phenolics. Journal of Agricultural and Food Chemistry. 33(2): 213-217. https://doi.org/10.1021/jf00062a013

Kamboj, V.P. 2000. Herbal medicine. Current Science. 78(1): 35-39.

Kolak, U., Hacibekiroğlu, I., Öztürk, M., Özgökçe, F., Topçu G., and Ulubelen, A. 2009. Antioxidant and anticholinesterase constituents of Salvia poculata. Turkish Journal of Chemistry. 33(6): 813-823. https://doi.org/10.3906/ kim-0902-1

Kumaran, A., and Karunakaran, R.J. 2007. In vitro antioxidant activities of methanol extracts of five Phyllanthus species from India. LWT-Food Science and Technology. 40(2): 344-352. https://doi.org/10.1016/j.lwt. 2005.09.011

Lui, C.H., Wang, C.H., Xu, Z-L., and Wang, Y. 2007. Isolation, chemical character-ization and antioxidant activities of two polysaccharides from the gel and theskin of Aloe barbadensis Miller irrigated with sea water. Process Biochemistry. 42(6): 961-970. https://doi.org/10.1016/j.procbio. 2007.03.004

Mariappan, V., and Shanthi, G. 2012. Antimicrobial and phytochemical analysis of Aloe vera L. International Research Journal of Pharmacy. 3(10): 158161.

Müller, L., Gnoyke, S., Popken, A.M., and Böhm, V. 2010. Antioxidant capacity and related parameters of different fruit formulations. $L W T$ - Food Science and Technology. 43: 992-999. https://doi.org/10.1016/j.lwt.2010.02.004 
Nagmoti, D., and Juvekar, A. 2013. In vitro inhibitory effects of Pithecellobium dulce (Roxb.) Benth. seeds on intestinal $\alpha$-glucosidase and pancreatic $\alpha$-amylase. Journal of Biochemical Technology. 4(3): 616-621.

Nampoothiri, S.V., Prathapan, A., Cherian, O.L., Raghu, K.G., Venugopalan, V.V., and Sundaresan, A. 2011. In vitro antioxidant and inhibitory potential of Terminalia bellerica and Emblica officinalis fruits against LDL oxidation and key enzymes linked to type 2 diabetes. Food and Chemical Toxicology. 49(1): 125-131. https://doi.org/10.1016/j.fct.2010.10.006

Okamura, N., Asai, M., Hine, N., and Yagi, A. 1996. High-performance liquid chromato-graphic determination of phenolic compounds in Aloe species. Journal of Chromatography A.746(2): 225-231. https://doi.org/ 10.1016/ 0021-9673(96)00342-1

Oryan, A., Mohammadalipour, A., Moshiri, A., and Tabandeh, M.R. 2016. Topical application of Aloe vera accelerated wound healing, modeling, and remodeling: an experimental study with significant clinical value. Annals of Plastic Surgery. 77(1): 37-46. https://doi.org/10.1097/SAP.0000 000000000239

Park, J.H., and Kwon, S.W. 2006. Chemical components of Aloe and its analysis: an epit-ome of chemical components and low molecular compounds. In: Park YI, Lee SK, editors. New Perspectives on Aloe. Boston, MA: Springer. p.19-34. https://doi.org/10.1007/0-387-34636-8-3

Ramkumar, K.M., Thayumanavan, B., Palvannan, T., and Rajaguru, P. 2010. Inhibitory effect of Gymnema montanum leaves on $\alpha$-glucosidase activity and $\alpha$-amylase activity and their relationship with polyphenolic content. Medicinal Chemistry Research. 19(8): 948-961. https://doi.org/10.1007/ s00044-009-9241-5

Ray, A., Dutta Gupta, S., and Ghosh S. 2012. Isolation and characterization of potent bioactive fraction with antioxidant and UV absorbing activity from Aloe barbadensis Miller gel. Journal of Plant Biochemistry and Biotechnology. 22(4): 483-487. https://doi.org/10.1007/s13562-012-0178-2

Ray, A., Dutta Gupta, S., and Ghosh, S. 2013. Evaluation of anti-oxidative activity and UV absorption potential of the extracts of Aloe vera $\mathrm{L}$. gel from different growth periods of plants. Industrial Crops and Products. 49: 712-719. https://doi.org/10.1016/j.indcrop.2013.06.008

Re, R., Pellegrini, N., Proteggente, A., Pannala, A., Yang, M., and Rice-Evans, C. 1999. Antioxidant activity aplying an improved ABTS radical cation decolorization assay. Free Radical Biology and Medicine. 26(9): 12311237. https://doi.org/10.1016/s0891-5849(98)00315-3

Rice-Evans, C., Miller, N., and Paganga, G. 1996. Structure-antioxidant activity relationship of flavonoids and phenolic acids. Free Radical Biology and Medicine. 20(3): 933-956. https://doi.org/10.1016/0891-5849(95)02227-9 
Rodriguez, E.R., Martin, J.D., and Romero, C.D. 2010. Aloe vera as a functional ingredient in foods. Critical Reviews in Food Science and Nutrition. 50(4): 305-326. https://doi.org/10.1080/10408390802544454

Saritha, V., Anilakumar, K.R., and Khanum, F. 2010. Antioxidant and antibacterial activity of Aloe vera gel extracts. International Journal of Pharmaceutical and Biological Archive. 1(4): 376-384.

Shobana, S., Sreerama, Y.N., and Malleshi, N.G. 2009. Composition and enzyme inhibitory properties of finger millet (Eleusine coracana L.) seed coat phenolics: mode of inhibition of $\alpha$-glucosidase and pancreatic amylase. Food Chemistry. 115(4): 1268-1273. https://doi.org/10.1016/j.foodchem. 2009.01.042

Sirdaarta, J., and Cock, I. 2008. Vitamin E and Trolox ${ }^{\mathrm{TM}}$ reduce toxicity of Aloe barbadensis miller juice in Artemia franciscana nauplii but individually are toxic at high concentrations. International Journal of Toxicology. 5: 1.

Sirdaarta, J., and Cock, I. 2010. Effect of Aloe barbadensis Miller juice on oxidative stress biomarkers in aerobic cells using Artemia franciscanaas a model. Phytotherapy Research. 24(3): 360-364. https://doi.org/10.1002/ ptr.2946

Taukoorah, U., and Mahomoodally, M.F. 2016. Crude Aloe vera gel shows antioxidant propensities and inhibits pancreatic lipase and glucose movement In Vitro. Advances in Pharmacological Sciences. 2016: Article ID 3720850. https://doi.org/10.1155/2016/3720850

Topçu, G., Ay, A., Bilici, A., Sarıkürkcü, C., Öztürk, M., and Ulubelen, A. 2007. A new flavones from antioxidant extracts of Pistacia terebinthus. Food Chemistry. 103(3): 816-822. https://doi.org/10.1016/j.foodchem. 2006.09.028

Walsh, G. 2003. Biopharmaceuticals: Biochemistry and Biotechnology. $3^{\text {rd }}$ ed. Chinchester: Wiley. Irland.

Yanlun, J., Ang, Z., Yulin, F., Min, L., Xianfang, Z., Hua, W., and Zhenwen, Z. 2016. Phenolic compounds and antioxidant activities of grape cane extracts from vineyards. Spanish Journal of Agricultural Research. 14(3): 1-13. https://doi.org/10.5424/sjar/2016143-8951

Yu, Z., Jin, C., Xin, M., and JianMin, H. 2009. Effect of Aloe vera polysaccharides on immunity and antioxidant activities in oral ulcer animal models. Carbohydrate Polymers. 75(2): 307-311. https://doi.org/10.1016/j. carbpol.2008.07.029

Zhang, S.Y., Zheng, C.G.,Yan, X.Y., and Tian,W.X. 2008. Low concentration of condensed tannins from catechu significantly inhibits fatty acid synthase and growth of MCF-7 cells. Biochemical and Biophysical Research Communications. 371(4): 654-658. 